\title{
Yeni kurulan bir tıbbi onkoloji bölümüne başvuran meme kanserli hastaların demografik verileri
}

\section{Demographic data of the patients with breast cancer referred to a newly settled medical oncology department}

\author{
Selim YALÇIN ${ }^{1}$, Eren Engin KAVAK², Süha ÇETIN ${ }^{2}$ \\ ${ }^{1}$ Kırıkkale Üniversitesi Tıp Fakültesi, İç Hastalıkları Anabilim Dalı, Onkoloji Bilim Dalı, Kırıkkale, \\ ${ }^{2}$ Kırıkkale Üniversitesi Tıp Fakültesi, İç Hastalıkları Anabilim Dalı, Kırıkkale, TÜRKiYE
}

\begin{abstract}
ÖZET
Amaç: Meme kanseri dünyada kadınlarda en sık görülen kanser tipidir. Yeni kurulan bir onkoloji merkezinde takip edilen meme kanserli olguların klinik ve patolojik özellikleri dökümante edilmek istendi.

Gereç ve Yöntemler: Mayıs 2012 - Aralık 2014 tarihleri arasında Kırıkkale Üniversitesi Tıp Fakültesi Araştırma ve Uygulama Hastanesi Tıbbi onkoloji polikliniğine başvuran ve takip edilen meme kanseri tanısı alan 56 hastanın klinik ve patolojik özelliklerini değerlendirildi. Hastalar yaş, cins, klinik evre patolojik özellikleri (histolojik tipi, hormon reseptör durumu, tümör greydi, çapı, pozitif lenf nodu tutulumu), hastaya verilen kemoterapiler ve diğer tedaviler, cerrahi tedavi şekli, metastaz bölgeleri değerlendirmeye alındı.

Bulgular ve Sonuç: Hastaların tamamı kadındı. Medyan yaş 54 yıl bulundu. Olguların 29 u \%52'si operabl, 22si \%40'ı metastatik, 4 ü \%8'i ise lokal ileri meme kanseri idi. Histolojik olarak hastaların; 40ı \%71,4 ü invazif duktal karsinom, 8i \%14'ü lobuler karsinom, 8 i \%14ü mikst karsinom idi. Estrogen reseptörü (ER) $33 \% 60$ hastada, progesteron reseptörü (PR) ise 31 $\% 56$ hastada pozitif değerlendirildiği saptandı. Erken evrede $43 \% 77$ modifiye radikal mastektomi, 12 \%21 lumpektomi, bir hastada ise basit mastektomi uygulanmıştı. Metastatik hastalarda lokalizasyonuna göre sırasıyla kemik, lökoregionel (ciltlokal-lenf nodu), karaciğer, akciğer ve plevra, beyin en sık tutulan bölgelerdi. Olguların $23 \% 41$ 'ine palyatif radyoterapi, 6 $\% 11^{\prime}$ ine sadece hormonal tedavi, $50 \% 89$ 'u kemoterapi kombinasyonu +/- hormonal tedavi verildi.
\end{abstract}

Anahtar Kelimeler: Meme kanseri, prognostik faktörler, demografi 


\section{ABSTRACT}

Aim: Breast cancer is the most common cancer among women in the world. The clinical and pathological characteristics in patients with breast cancer were evaluated at a newly established oncology center.

Material and Methods: Demographic characteristics of 56 breast cancer patients which have been followed between May 2012 and December 2014, were evaluated according to their clinical and pathological features. Patients were classified according to their age, gender, clinical stage, pathologic features (histological subtype, grade, size, hormone receptor status, lymph node status), type of treatment, surgical procedure, and site of metastasis.

Results and Conclusion: All patients were female and median age was 54 years. Among them 29 (52\%) was operable and 22 (40\%) were metastatic breast cancer, whereas 4 (8\%) were locally advanced breast cancer. Histologically, invasive ductal carcinoma, lobulary carcinoma, and mix carcinoma were found in 40 (71.4\%), 8 (14\%), and 8 (14\%) cases, respectively. 33 (60\%) patients were estrogen receptor (ER) positive and 31 (56\%) patients were progesterone receptor (PR) positive. In early breast cancer, 43 (77\%) patients had undergone modified radical mastectomy, 12 (21\%) patients were treated by lumpectomy, and one patient had undergone simple mastectomy. In metastatic breast cancer; sites of metastasis were bone, locally and regionally; liver, lung and pleura, and brain. 23 (41\%) patients with metastatic breast cancer had received palliative radiation therapy, $6(11 \%)$ had only hormonal therapy and 50 (89\%) had chemotherapy with or without hormonal therapy.

Key words: Breast cancer, prognostic factors, demographic properties

\section{Giriş}

Kanser türleri açısından bakıldığında, meme kanserinin birçok ülkede kadınların sağlığını etkileyen önemli bir kanser türü olduğu bilinmektedir. Erken tanı yöntemlerinin gelişmesi ve tedavideki ilerlemelere rağmen halen önemli bir mortalite ve morbidite nedenidir. Literatürde yer alan bilgiler incelendiğinde; dünyada her üç dakikada bir kadına meme kanseri tanısı konulduğu ifade edilmektedir [1].

Erken evre meme kanserli hastalarda etkin ve yeterli bir tedavi kür sağlayıcı iken metastatik hastalarda tam bir şifa sağlamak ne yazık ki mümkün değildir. Tüm bu iki gurupta yani hem erken hem de metastatik hastalarda tedavi planlarken yol gösterici olan çeşitli faktörler bulunmaktadır. Opere edilecek erken evre meme kanserinde tedavi seçimini etkileyen önemli hususlar, hastanın yaşı, tümörün çapı, aksillada metastatik lenf nodunun olup olmaması ve sayısı, menapoza girip girmediği, histolojik alt tipi ve diferansiasyon derecesi, östrojen reseptörü (ER), progesteron reseptörü (PR) ve büyüme faktörü reseptörü olan CerbB2 veya diğer adı ile HER-2 durumudur. Metastatik hastalarda ise bunlara ilaveten metastazın yeri ve yaygınlığı, hastanın performansı, CerbB2 durumu hastalığın prognozunu ve tedavi seçimini belirlemede önemlidirler [1-3].

Kırıkkale'de ilk onkoloji merkezi olmamı nedeniyle meme kanserli vakalarımızın demografik, patolojik ve klinik özelliklerini sunmayı uygun bulduk.

\section{Gereç ve Yöntem}

Kırıkkale ilinde ilk kez kemoterapi düzenli olarak Mayıs 2013'te başladı. Çalışmamıza Kırıkkale Üniversitesi Tıp Fakültesi Araştırma ve Uygulama Hastanesi Tıbbi onkoloji polikliniğine başvuran, Mayıs 2013-Aralık 2014 tarihleri arasında takip edilen meme kanseri tanısı alan 56 hasta alındı. Meme kanseri hastaları retrospektif olarak klinik ve patolojik özellikleri açısından değerlendirildi. İstatistiksel analizler için "SPSS for Windows 17.0 versiyonu" kullanıldı.

\section{Bulgular}

Meme kanseri tanısı ile onkoloji polikliniğine başvuran 56 kadın hasta çalışmaya alındı. Hastaların ortanca yaşı 54 (3086) idi. Hastaların çoğunluğunu 36'sı (\%65) 50 yaş ve üzeri hastalardan oluşmaktaydı. Menarş yaşı ortanca 13 (11-15) olarak saptandı. Olguların 35'si (\%64) postmenapozaldi (Tablo 1). Genel olarak tüm hastalara bakıldığında ailede meme kanseri öyküsü hastaların \%10'unda mevcuttu.

Tablo 1. Hastaların Demografik Özellikleri

\begin{tabular}{|l|l|}
\hline Hasta sayısı & 56 \\
\hline Yaş ortanca & 54 \\
\hline Yaş & \\
$<50$ & $20(\% 36)$ \\
$>50$ & $36(\% 64)$ \\
\hline Premenapozal & $20(\% 36)$ \\
\hline Postmenapozal & $36(\% 64)$ \\
\hline
\end{tabular}

Hastaların 35'i (\%64) çocuk sahibiydi. Çocuk sahibi olma oranı 2 ve daha fazlası $\% 68$, bir yıl ve daha fazla emzirme oranı ise çocuk sahibi olanlarda \% 80, her iki memeden emzirme oranı da \%71 olarak bulundu. Kontraseptif kullanımı 3 vakada (\%6) saptandı. Sadece bir hastanın hormon replasman tedavisi aldığı gözlendi. Hastaların 20'sinde (\%36) sigara içiciliği saptandı.

Olguların 29'sında (\%51,7) tümör sağ memede, 26'sında $(\% 46,4)$ sol meme bir hastada \% 1,7' sinde de her iki memede saptandı. Tümörün histolojik tiplerine göre dağılımı ise en sık invaziv duktal karsinom 40'ında $(\% 71,4)$, sonra sırasıyla invaziv lobuler karsinom 8 'inde (\%14) ve mikst tip 8'inde (\%14) gözlendi (Tablo 2).

Tümörlerin histopatolojik verileri bakılırsa, en sık Evre II hastalık saptanırken başvuruda metastaz hastaların 20'sinde (\%35) gözlenmiştir. Hastaların 20'sinde (\%35) lenf nodu metastazı saptanmazken lenf nodu pozitif hastaların çoğunluğunda (18'inde) 1-3 lenf nodu metastazı saptanmıştır (N1 \%33). Hastaların 33'ünde (\%60) Östrojen reseptörü (ER) pozitiftiği, CerbB2 pozitifliği ise 15 hastada (\%26) bulundu (Tablo 2). 
Tablo 2. Hastaların Tanı anında patolojik özellikleri

\begin{tabular}{|c|c|c|}
\hline \multicolumn{3}{|l|}{ Histolojik tipler } \\
\hline İnvaziv duktal karsinom (IDC) & 40 & 71 \\
\hline İnvaziv lobuler karsinom (ILC) & 8 & 14 \\
\hline Mikst & 8 & 14 \\
\hline \multicolumn{3}{|l|}{ Aksillar Lenf Nodu tutulumu } \\
\hline Pozitif & 20 & 35 \\
\hline Negatif & 36 & 65 \\
\hline \multicolumn{3}{|l|}{ CerbB2 } \\
\hline \multicolumn{3}{|l|}{0} \\
\hline \multicolumn{3}{|l|}{$1+$} \\
\hline $2+$ & 2 & 3 \\
\hline $3+$ & 13 & 23 \\
\hline \multicolumn{3}{|l|}{ Hormon Reseptör Statusu } \\
\hline $\mathrm{ER}+\mathrm{PR}+$ & 34 & 60,7 \\
\hline ER-PR + & 5 & 8,9 \\
\hline PR+ ER- & 7 & 12,5 \\
\hline PR- ER- & 10 & 17,8 \\
\hline
\end{tabular}

Metastazla başvuran hastalarda en sık metastaz yeri kemik $n=45$ (\%80) iken ikinci sıklıkta akciğer $n=8$ (\%14) metastazı saptanmıştır.

Cerrahi tedavi yöntemlerine bakıldığında 43'üne

(\%77) modifiye radikal mastektomi, 12'sine (\%22) meme koruyucu cerrahi yapıldığı, bunlardan hiçbirine sentinal lenf nodu biyopsisi uygulanmamıştır.

Hastaların 50' sine (\% 89) kemoterapi verildi. Bu tedaviler 31 'inde (\%56) antrasiklin, \%36'sında antrasiklin + taksan bazlı kemoterapi rejimleri olarak uygulandı.

Hormon reseptörü pozitif olan hastaların 43'ü (\%78) başlangıçtan itibaren veya kemoterapi sonrası endokrin tedavi başlandı. Bunların çoğunluğunu aromataz inhibitörleri 15'inde (\%36) oluştururken, \%28 hastaya tek başına tamoksifen verildi. Radyoterapi ise hastaların 32'sine (\%58) uygulandı.

\section{Tartışma}

Meme kanseri, kadınlarda en sık görülen ve ikinci sıklıkta ölüme neden olan malign hastalık olup, görülme riski yaş ile artmaktadır. İstatistiklere göre kadınlarda görülen kanserler içinde \%24,1 ile ilk sırada yer almaktadır [4]. Batı toplumunda tüm meme kanserlerinin \%5-7'si 40 yaş altında iken, Türkiye' de bu oran \%20 civarındadır [5,6]. Türkiye'den bir grup araştırıcı 11.208 meme kanserli hasta üzerinde yaptıkları çalışmada meme kanserinin \%31'inin 40-50 yaş arasında, \%20,2'sinin 40 yaşın altındaki kadınlarda görüldüğünü tespit etmişlerdir [5]. Bizim çalışmamız da ülkemizdeki oranlara yakın olup 50 yaş ve altı hasta oranı \%36 saptanmıştır. Çalışmada ortanca yaş 56 olup, 40-50 yaş arası hasta oranımız ise \%20 tespit edildi.

Meme kanseri, farklı histolojik ve biyolojik özelliklere sahip olup, bu özellikler kişiden kişiye değişmektedir [7]. Meme kanserinde bilinen prognostik faktörler tümör boyutu, tutulan lenf düğümü sayısı, histolojik ve nükleer derece ve hormon reseptörü durumlarıdır [8]. Çalışmamızda elde edilen veriler değerlendirildiğinde tanı sırasında Evre I ve II olarak değerlendirilen olgu oranı \%65, Evre III-IV olarak değerlendirilen lokal ileri ve metastatik olgu oranı ise \%35 tespit edildi. Ulusal Meme Kanseri Kayıt Programı verilerinde, tüm yaş grubundaki hastalarda Evre I ve II görülme oranının $\% 79,6$, sadece Evre II görülme oranının \%52,8 ve sadece Evre III görülme oranının da \%9 olduğu görülmektedir [9]. Bizim çalışmamızda Evre III hasta oranı \%20 saptanmış olup literatüre göre ileri evre oranlarımız daha yüksek, erken evre oranlarımız ise daha düşüktür.

Ulusal Meme Kanseri Kayıt Programı verilerinde, tüm yaş gruplarındaki olgularda CerbB-2 pozitiflik oranının \% 17,5 olduğu görülmüştür [5]. Çalışmamızda \%26 oranında CerbB-2 pozitifliği saptanmıştır. Çalışmamızda literatüre göre daha yüksek oranda Cerb-B2 pozitifliği saptanmış olup bu merkezimizin yeni olması ve az hasta sayısı ile açıklanabilir. Hasta sayısı arttıkça verilerin daha istatistiki anlamlı olacağına inanıyoruz. Çalışmamız küçük bir merkezde, az sayıda hastada yapılmıştır. Türkiye genelinde bu gibi yeni açılan küçük merkezlerin verilerinin daha fazla toplanması ve daha fazla hasta sayısı içeren çok merkezli çalışmaların yapılması gerekmektedir.

Hasta sayımız ve takibi kısa olduğundan sağ kalım verileri bildirilmemiştir. Bu hastaların merkezimizdeki takipleri arttıkça bu verileri de içeren daha büyük çalışmalara ihtiyaç vardır.

\section{Çıkar çatışması ve Finansman Beyanı}

Bu çalışmada çıkar çatışması ve finansman destek alındığı beyan edilmemiştir.

\section{Kaynaklar}

1. Greenlee RT, Hill-Harmon MB, Murray T, Thun M. Cancer statistics, 2001. CA Cancer J Clin 2001; 51: 15-36.

2. Öztop I, Alakavuklar M. Metastatik meme kanserinde kemoterapi. Hematoloji-Onkoloji Güncel Derleme Dergisi 2001; 3: 128-36.

3. Pak I. Erken evre meme kanserinde prognostik faktörler, Hematoloji- Onkoloji Güncel Derleme Dergisi 2001; 3: 79-83.

4. Stewart SL, King JB, Thompson TD, Friedman C, Wingo PA. Cancer mortality surveillance United States, 1990-2000. MMWR Surveill Summ 2004; 53: 1-108.

5. Ozmen V. Breast cancer in the world and Turkey. The Journal of Breast Health 2008; 4: 7-12.

6. Bland KI, Menck HR, Scott-Conner CE, Morrow M, Winchester DJ, Winchester DP. The National Cancer Data Base 10-year survey of breast carcinoma treatment at hospitals in the United States. Cancer 1998; 83: 1262-73.

7. saacs C, Stearns V, Hayes DF. New Prognostic Factors for Breast Cancer Recurrence. Seminars in Oncology, 2001; 28: 53-67.

8. Esteva FJ, Sahin AA, Cristofanilli M, Arun B, Hortobagyi GN. Molecular prognostic factors for breast cancer metastasis and survival. Semin Radiat Oncol 2002; 12: 319-28.

9. Özmen V,Fidaner C, Aksaz E, Bayol Ü ve ark. Türkiye'de Meme Kanseri Erken Tanı ve Tarama Programlarının Hazırlanması. The Journal of Breast Health 2009; 5: 125-134. 